Resona Jurnal Ilmiah Pengabdian Masyarakat Vol. 2, No. 1 (2018) 1-11

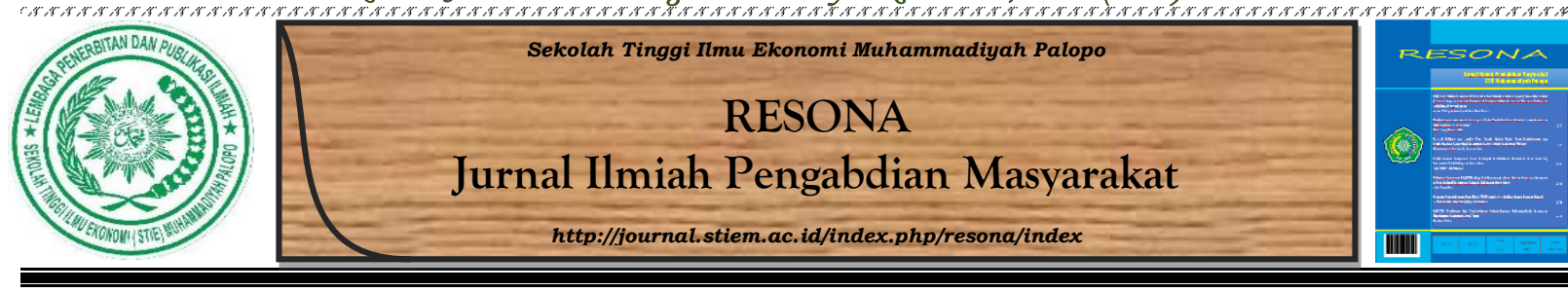

\title{
PKM Pengelolaan Keuangan Desa Secara Profesional Menuju Desa yang Kuat dan Mandiri (Sasaran Program: Aparatur Pemerintah Gampong dalam Kecamatan Meureubo Kabupaten Aceh Barat Provinsi Aceh)
}

Zainal Putra ${ }^{1}$, Budianto $^{2}$, Cut Devi Maulidasari ${ }^{3}$

1,2,3 Universitas Teuku Umar Aceh

INFO NASKAH
Diserahkan
23 Juni 2018
Diterima
23 Juni 2018
Diterima dan disetujui
29 Juni 2018

\section{Kata Kunci:}

Dana desa

Pengelolaan keuangan desa

Penyelewengan dana desa

P,

\begin{abstract}
ABSTRAK Tujuan Pengabdian Kepada Masyarakat (PKM) ini adalah meningkatkan profesionalitas aparatur pemerintah gampong dalam pengelolaan dana desa. Selain itu, program ini sangat berguna sebagai upaya untuk melakukan pencegahan dini potensi penyelewengan dana desa, sehingga para pengelola dana desa dapat terhindar dari masalah hukum di kemudian hari. Sasaran progam ini adalah aparatur pemerintah gampong dalam Kecamatan Meureubo Kabupaten Aceh Barat, di mana setiap gampong diwakili oleh tiga orang, terdiri dari Keuchik, Bendahara Gampong, dan Ketua Tim Pelaksana Kegiatan (TPK). Metode pelaksanaan dilakukan dengan memberikan pelatihan dan praktik serta tanya jawab terkait dengan pengelolaan keuangan desa. Materi pelatihan yang diberikan mencakup perencanaan, pelaksanaan, penatausahaan, pertanggungjawaban, dan pelaporan keuangan desa. Pelatihan ini melibatkan tenaga ahli keuangan desa dari Pemerintah Kabupaten Aceh Barat dan sebagai asisten tim pengabdian turut dilibatkan mahasiswa dari Fakultas Ekonomi Universitas Teuku Umar. Hasil yang dicapai dari program pengabdian ini adalah: (a) meningkatnya sistem akuntabilitas pengelolaan keuangan desa; (b) meningkatnya keterampilan aparatur pemerintah gampong dalam penatausahaan keuangan desa; (c) terhindarnya masalah hukum terkait dengan pengelolaan keuangan desa pada aparatur pemerintah desa; dan (d) meningkatnya kepercayaan masyarakat kepada aparatur pemerintah gampong.
\end{abstract}

\section{Pendahuluan}

Visi Tri Sakti Presiden periode tahun 2014-2019 meletakkan program pemerintah pada titik berat pencapaian ideal bangsa Indonesia pada kedaulatan politik, kemandirian ekonomi, dan kepribadian budaya. Untuk merealisasikan visi tersebut pemerintah bertekad (dalam Nawa Cita) membangun Indonesia dari pinggiran dengan memperkuat daerah-daerah dan desa dalam 
kerangka Negara Kesatuan Republik Indonesia. Salah satu wujud rekognisi negara kepada desa adalah penyediaan dan penyaluran dana desa yang bersumber pada Anggaran Pendapatan dan Belanja Negara (APBN).

Sebagai langkah nyata, pemerintah telah menganggarkan secara resmi dana desa dalam APBN mulai tahun 2015. Berdasarkan Peraturan Presiden RI Nomor 36 Tahun 2015, lampiran XXII diperoleh informasi bahwa tahun 2015 pemerintah mengalokasikan dana desa dengan jumlah keseluruhan sebesar Rp20.766.200.000.000. Jumlah tersebut merupakan 1,047\% dari total anggaran belanja negara tahun 2015 sebesar Rp1.984.149.714.865.000. Kemudian di tahun 2016 alokasi dana desa dalam APBN meningkat secara signifikan. Data dari Peraturan Presiden Nomor 66 Tahun 2016, lampiran XVIII diketahui alokasi dana desa dalam APBN TA 2016 sebesar Rp46.982.080.000.000 atau 2,256\% dari total anggaran belanja negara tahun 2016 sebesar Rp2.082.948.885.885.000. Dana desa tersebut disalurkan kepada 74.754 desa seluruh Indonesia. Bila dirata-ratakan setiap desa mendapat alokasi dana sebesar Rp628.489.178.

Secara spesifik, untuk Kabupaten Aceh Barat mendapat alokasi dana desa TA 2016 sebesar Rp189.083.713.000, yang diperuntukkan bagi 322 desa yang terdapat dalam Kabupaten Aceh Barat. Bila dibagi rata maka setiap desa akan memperoleh dana desa sebesar Rp587.216.500. Penggunaan dana desa diprioritaskan untuk membiayai pembangunan dan pemberdayaan masyarakat yang pelaksanaannya diutamakan secara swakelola dengan menggunakan sumber daya/bahan baku lokal, dan diupayakan lebih banyak menyerap tenaga kerja dari masyarakat desa setempat (Pasal 5 ayat 1, Permendes No. 21 Tahun 2015).

Peraturan Menteri Keuangan Nomor 93 Tahun 2015 tentang Tata Cara Pengalokasian, Penyaluran, Penggunaan, Pemantauan, dan Evaluasi Dana Desa, menyatakan bahwa dana desa disalurkan dari Rekening Kas Umum Negara (RKUN) ke Rekening Kas Umum Daerah (RKUD) setiap tahun anggaran. Penyaluran dana desa dari RKUN ke RKUD dilakukan dalam tiga tahap yaitu pada bulan April sebesar 40\%, tahap kedua pada bulan Agustus sebesar 40\% dan tahap ketiga pada bulan Oktober sebesar $20 \%$.

Setelah sampai di desa, dana dikelola oleh aparatur pemerintahan desa dengan struktur pengelola keuangan desa sebagaimana dijelaskan dalam Peraturan Menteri Dalam Negeri Nomor 113 Tahun 2014 tentang Pengelolaan Keuangan Desa, meliputi:

a. Kepala Desa selaku pemegang kekuasaan pengelola keuangan desa dan mewakili pemdes dalam kepemilikan kekayaan milik desa yang dipisahkan. 
b. Sekretaris Desa, bertindak selaku koordinator pelaksana teknis pengelolaan keuangan desa (TPKD).

c. Kasi bertindak selaku pelaksana kegiatan sesuai bidangnya.

d. Bendahara, dijabat oleh staf pada urusan keuangan.

Pada prinsipnya dalam pengelolaan dana desa harus transparan, akuntabel, partisipatif, tertib, disiplin anggaran, dan konsisten. Peraturan Menteri Dalam Negeri Nomor 113 Tahun 2014 tentang Pengelolaan Keuangan Desa, pasal 41 ayat (2), dinyakatan bahwa kepala desa wajib menyampaikan laporan pertanggungjawaban realisasi pelaksanaan APBDesa paling lambat satu bulan setelah akhir tahun anggaran. Laporan tersebut yang utama diinformasikan kepada masyarakat secara tertulis dengan media informasi yang mudah diakses masyarakat seperti papan pengumuman, radio komunitas, dan media informasi lainnya. Selain itu, laporan realisasi dan laporan pertanggungjawaban pelaksanaan APBDesa kepada bupati/walikota melalui camat.

Masalah yang muncul di sini adalah para pengelola keuangan di desa belum cakap dalam melakukan pengelolaan keuangan desa. Mulai dari perencanaan, pelaksanaan, hingga pertanggungjawabannya banyak ditemukan masalah. Berdasarkan informasi yang diberitakan media massa, pengelolaan keuangan desa banyak sekali timbul masalah. Berikut kami sajikan cuplikan beberapa informasi terkait berbagai permasalahan dalam pengelolaan dana desa yang dimuat di media massa:

a. Aparat kepolisian di Nagan Raya melakukan pengusutan dan pengejaran terhadap Sb (50), Keuchik Gampong Blang Murong, Kecamatan Seunagan, yang kini dikabarkan menghilang usai menarik dana desa dari sebuah bank yang mencapai Rp100 juta. Akibatnya dana yang seharusnya digunakan untuk melakukan sejumlah pembangunan di desa setempat, kini tidak diketahui keberadaannya. Bahkan sang keuchik juga tidak diketahui keberadaannya (http://aceh.tribunnews.com, Senin, 14 September 2015).

b. Warga Gampong Ujong Padang, Kecamatan Sawang, Aceh Selatan, menuding keuchik setempat telah menggelapkan uang desa sebesar Rp114.200.000. Menurut mereka terdapat beberapa program yang sudah dialokasikan dananya dalam APBG tahun 2015, namun tidak dilaksanakan keuchik. Selain itu juga dituding banyak realisasi dana yang menyimpang dari ketentuan yang telah ditetapkan (http://aceh.tribunnews.com, Kamis, 17 Maret 2016).

c. Rapat pertanggungjawaban penggunaan dana desa tahun 2015 di Gampong Biram Rayeuk, Kecamatan Tanoh Jambo Aye, Aceh Utara dihujani interupsi dan ricuh. Bahkan Keuchik 
Biram Rayeuk, Syukri Daud dilaporkan pingsan dan dipapah oleh warga ke rumahnya (http://aceh.tribunnews.com, Senin, 4 April 2016).

d. Sekitar 128 warga Gampong Jalan, Kecamatan Idi Rayeuk, Aceh Timur menolak laporan pertanggungjawaban (LPj) Alokasi Dana Gampong (ADG) tahun 2015 yang dibuat oleh tim pelaksana kegiatan di Gampong. Hal tersebut dikarenakan pembangunan beberapa proyek Gampong, tidak dikerjakan sesuai dengan rencana anggaran biaya. Selain itu, tidak dilakukan rapat dengan masyarakat dalam melakukan perencanaan dan pelaksanaan kegiatan yang menggunanan dana desa (http://aceh.tribunnews.com, Selasa, 17 Mei 2016).

Beberapa fakta yang ditelah diuraikan di atas, kami dari pihak Fakultas Ekonomi Universitas Teuku Umar, merasa terpanggil untuk melakukan pencerahan dan peningkatan kapasitas kepada aparatur pemerintah desa dalam hal pengelolaan keuangan desa. Hal ini sangat berguna sebagai upaya untuk melakukan pencegahan dini potensi penyelewengan dana desa, sehingga para pengelola dana desa dapat terhindar dari masalah hukum di kemudian hari. Selain itu, dengan meningkatnya profesionalitas pengelola dana desa, maka dapat meningkatkan kepercayaan masyarakat terhadap aparatur pemerintah desa. Dengan demikian tujuan pemerintah untuk meningkatkan perekonomian desa, mengurangi kemiskinan dan pengangguran dapat diwujudkan segera.

Oleh karena itu, kami kemas kegiatan ini dalam bentuk pengabdian kepada masyarakat dengan tema "Pengelolaan Keuangan Desa Secara Profesional, Menuju Desa yang Kuat dan Mandiri (Sasaran Program: Aparatur Pemerintah Desa dalam Kecamatan Meureubo Kabupaten Aceh Barat).

\section{Permasalahan Mitra}

Hasil wawancara awal yang kami lakukan dengan pihak mitra, yaitu BPKD Kabupaten Aceh Barat selaku penyalur dana dari kas daerah ke rekening desa, DPMG Kabupaten Aceh Barat selaku pembina dana desa ditingkat kabupaten, serta pihak kecamatan selaku koordinator dan pembina dana desa di tingkat kecamatan, pihak mereka pada dasarnya telah melakukan pelatihan dan pendampingan kepada aparatur pemerintah desa terhadap pengelolaan keuangan desa.

Namun demikian, hal tersebut dirasa belum cukup dikarenakan jangkauan yang sangat luas dengan sebanyak 322 desa yang terdapat di Kabupaten Aceh Barat. Selain itu jumlah tenaga ahli di bidang keuangan desa masih sangat terbatas, ditambah lagi dengan alokasi dana 
operasional untuk pendampingan ke desa belum memadai disediakan dari pemerintah kabupaten. Hal tersebut telah menjadi kendala bagi mereka untuk melakukan pendampingan secara berkelanjutan bagi seluruh lingkup desa dalam Kabupaten Aceh Barat.

Informasi hasil wawancara dan pengamatan yang kami lakukan bahwa aparatur pemerintahan desa yang terlibat dalam pengelolaan keuangan desa masih kesulitan dalam hal mengelola dana desa (seperti membuat perencanaan, pelaksanaan hingga pertanggungjawaban keuangan desa). Secara terperinci permasalahan yang dihadapi oleh aparatur pemerintah desa dalam pengelolaan keuangan desa meliputi perencanaan keuangan desa, pelaksanaan keuangan desa, penatausahaan keuangan desa, pertanggungjawaban, dan pelaporan keuangan desa. Timbulnya permasalahan tersebut disebabkan kebanyakan dari pengelola dana desa tersebut belum memiliki pemahaman dan keterampilan yang memadai terhadap manajemen keuangan desa. Juga pada umumnya mereka masih berpendidikan tingkat rendah terutama pada desa-desa pelosok.

Melalui kegiatan pengabdian kepada masyarakat ini, kami menawarkan solusi kepada mitra dalam pengelolaan keuangan desa meliputi:

a. Peningkatan pengetahuan dan pemahaman tentang tata cara perencanaan keuangan desa.

b. Peningkatan pengetahuan dan pemahaman tentang tata cara pelaksanaan keuangan desa.

c. Peningkatan pengetahuan dan pemahaman tentang tata cara penatausahaan keuangan desa.

d. Peningkatan pengetahuan dan pemahaman tentang tata cara pertanggungjawanan dan pelaporan keuangan desa.

\section{Metode Pelaksanaan}

Sasaran PKM ini adalah sebanyak 78 aparatur pemerintahan desa, yang mencakup 26 gampong dalam Kecamatan Meureubo Kabupaten Aceh Barat. Tiap gampong diundang sebanyak 3 orang aparatur yang terdiri dari Keuchik, Bendahara gampong dan Ketua Tim Pelaksana Kegiatan (TPK). Sebagian Pemeritah Kabupaten Aceh Barat juga dilibatkan dalam kegiatan ini masing-masing satu orang dari Badan Pengelolaan Keuangan Daerah Kabupaten Aceh Barat, Dinas Pemberdayaan Masyarakat dan gampong Kabupaten Aceh Barat dan Kantor Camat Meureubo Kabupaten Aceh Barat. Pelibatan tim dari Pemeritah Kabupaten Aceh Barat dipandang sangat perlu, mengingat pemerintah desa merupakan bagian dari pemerintah kabupaten itu sendiri.

Metode pelaksanaan kegiatan ini dilakukan dengan memberikan pelatihan/workshop plus praktik/latihan serta tanya jawab terkait dengan pengelolaan keuangan desa. Kegiatan seperti 
ini dirasakan sangat perlu bagi aparatur pemerintahan desa, mengingat minimnya pengetahuan mereka terkait dengan sistem pengelolaan keuangan desa. Adapun materi pelatihan yang diberikan adalah perencanaan keuangan desa, pelaksanaan keuangan desa, penatausahaan keuangan desa, pertanggungjawaban dan pelaporan keuangan desa, serta diakhiri dengan latihan dan tanya jawab.

\section{Hasil dan Pembahasan}

Program pengabdian kepada masyarakat ini telah sukses dilaksanakan dan berjalan lancar sesuai dengan yang direncanakan. Pelaksanaannya dilakukan pada hari Kamis, tanggal 31 Mei 2018, yang bertempat di Aula SMAN 1 Meureubo, Paya Peunaga. Adapun sasaran program adalah aparatur pemerintah gampong dalam Kecamatan Meureubo Kabupaten Aceh Barat Provinsi Aceh. Namun demikian, secara keseluruhan kegiatan ini memakan waktu selama lebih kurang 3 bulan.

Tabel 1. Jadwal Pelaksanaan Kegiatan

\begin{tabular}{|c|l|c|c|c|}
\hline \multirow{2}{*}{ No. } & \multicolumn{1}{|c|}{ Kegiatan } & \multicolumn{2}{c|}{ Bulan } \\
\cline { 3 - 4 } & \multicolumn{1}{|c|}{1} & 2 & 3 \\
\hline 1. & Perencanaan program. & & & \\
\hline 2. & Komunikasi dan koordinasi dengan stakeholder. & & \\
\hline 3. & $\begin{array}{l}\text { Pelaksanaan program, administrasi dan dokumentasi, } \\
\text { finalisasi laporan dan penyiapan naskah jurnal. }\end{array}$ & & & \\
\hline
\end{tabular}

Sedangkan bahan pembelajaran yang diberikan pada saat pelaksanaan pelatihan sebagaimana disajikan dalam tabel berikut ini.

Tabel 2. Jadwal Pelaksanaan Kegiatan

\begin{tabular}{|c|l|c|}
\hline Pukul (WIB) & \multicolumn{1}{|c|}{ Materi } & Keterangan \\
\hline $08.00-08.30$ & Registrasi Peserta & Panitia \\
\hline $08.30-08.40$ & Pembukaan & Ketua Tim Pengabdian \\
\hline $08.40-08.50$ & Sambutan dari Ketua Panitia & Camat Meureubo \\
\hline $08.50-09.50$ & $\begin{array}{l}\text { Gambaran Umum Pengelolaan Keuangan Desa di Gampong } \\
\text { dalam Kecamatan Meureubo }\end{array}$ & DPMG Kab. Aceh Barat \\
\hline $09.50-10.50$ & Perencanaan Keuangan Desa & DPMG Kab. Aceh Barat \\
\hline $10.50-11.00$ & Moderator \\
\hline $11.00-12.00$ & $\begin{array}{l}\text { - Perencanaan Keuangan Desa } \\
\text { - Diskusi/Tanya Jawab }\end{array}$ & $\begin{array}{c}\text { BPKD Kab. Aceh Barat } \\
\text { - Pokok-Pokok Pengelolaan Keuangan Desa }\end{array}$ \\
\hline $12.00-12.30$ & $\begin{array}{l}\text { - Pelaksanaan Keuangan Desa } \\
\text { - Pertanggungjawaban dan Pelaporan Keuangan Desa }\end{array}$ & DPMG Kab. Aceh Barat \\
\hline $14.00-15.30$ & $\begin{array}{l}\text { - Pokok-Pokok Pengelolaan Keuangan Desa } \\
\text { - Pelaksanaan Keuangan Desa }\end{array}$ & Moderator \\
\hline
\end{tabular}


Resona Jurnal Ilmiah Pengabdian Masyarakat, 1 (2018): 1-11

\begin{tabular}{|c|l|c|}
\hline $15.30-16.00$ & Penatausahaan Keuangan Desa & Ketua Tim Pengabdian \\
\hline $16.00-16.30$ & \multicolumn{1}{|c|}{ SHALAT ASHAR / ISTIRAHAT } & \\
\hline $16.30-17.30$ & $\begin{array}{l}\text { - Praktik Penatausahaan Keuangan Desa } \\
-\quad \text { Diskusi/Tanya Jawab }\end{array}$ & $\begin{array}{c}\text { Ketua Tim Pengabdian } \\
\text { Moderator }\end{array}$ \\
\hline $17.30-18.00$ & Penutup & Moderator \\
\hline
\end{tabular}

Kami turut melibatkan mahasiswa Fakultas Ekonomi Universitas Teuku Umar dalam pelaksanaan program ini dengan tujuan supaya mereka dapat merasakan pengalaman lapangan dan belajar membangun hubungan yang baik dengan masyarakat, yakni: (a) TM Zairif Luqmazi, NIM 1705906020037, Mahasiswa Prodi S1 Manajemen; (b) Zaini, NIM 1705906020024, Mahasiswa Prodi S1 Manajemen; (c) Zulfahmi, NIM 1705906020026, Mahasiswa Prodi S1 Manajemen; (d) Taufiq Qurrahman, NIM 1605906020025; (e) Julia Fita, NIM 1705906020060, Mahasiswa Prodi S1 Manajemen; dan (f) Agusuwantri, NIM 1605906010069, Mahasiswa Prodi S1 Ekonomi Pembangunan.

Guna mendapatkan umpan balik (feedback) dari peserta pelatihan, kami menyebarkan lembar evaluasi kegiatan pada akhir acara, yang terdiri dari tanggapan peserta pelatihan terhadap lima aspek yaitu: (a) pelaksanaan kegiatan, (b) manfaat kegiatan, (c) penunjang kegiatan, (d) modul pelatihan, dan (e) profesionalitas narasumber. Terdapat 21 (dua puluh satu) item pernyataan yang harus diberikan oleh peserta pelatihan, yaitu terdiri dari aspek pelaksanaan kegiatan sebanyak 5 pernyataan, aspek manfaat kegiatan sebanyak 5 pernyataan, aspek penunjang kegiatan sebanyak 2 pernyataan, aspek modul pelatihan sebanyak 4 pernyataan, dan aspek profesionalitas narasumber sebanyak 5 pernyataan.

Mereka diberikan empat skala yaitu: $1=$ sangat tidak puas, $2=$ tidak puas, $3=$ puas, dan 4 = sangat puas. Kesimpulan dari hasil evaluasi kami adalah sebagai berikut:

a. Secara keseluruhan peserta memberikan tanggapan sangat puas terhadap aspek pelaksanaan kegiatan, manfaat kegiatan, modul pelatihan, dan profesionalitas narasumber. Hal ini dapat dimaknai bahwa kegiatan ini telah dilaksanakan dengan sungguh-sungguh, bermanfaat bagi peserta pelatihan, dan didukung dengan penyiapan bahan pembelajaran yang memadai serta dilatih oleh narasumber yang sangat profesional di bidangnya.

b. Aspek penunjang kegiatan secara keseluruhan peserta memberikan tanggapan puas. Hal ini dapat dimengerti karena masih terdapat beberapa kekurangan dalam hal sarana penunjang baik berupa tempat pelatihan maupun perlengkapan pelatihan. Kondisi tersebut disebabkan kami menggunakan ruang aula SMAN 1 Meureubo sebagai tempat pelatihan, di mana ruangan tersebut tidak dilengkapi dengan Air Conditioning (AC) dan juga mobeleur tidak tersedia, sehingga kami harus memobilisasi beberapa kipas angin pribadi dan memobilisasi 
kursi mahasiswa Fakultas Ekonomi Universitas Teuku Umar ke tempat pelaksanaan kegiatan.

Sudut pandang masing-masing individu peserta pelatihan, diketahui bahwa sebanyak $80 \%$ peserta pelatihan menyatakan sangat puas atas penyelenggaraan kegiatan pelatihan ini. Sedangkan sisanya sebanyak $20 \%$ peserta pelatihan menyatakan puas atas penyelenggaraan kegiatan pelatihan. Sehingga dapat disimpulkan bahwa pelaksanaan kegiatan pengabdian kepada masyarakat ini dapat dikatakan berhasil dan sukses. Selain itu, di akhir acara kami juga meminta testimoni terkait pelaksanaan kegiatan ini dari peserta pelatihan setiap gampong.

Tabel 3. Beberapa Testimoni Peserta Pelatihan

\begin{tabular}{|c|c|c|}
\hline No. & Peserta Pelatihan & Testimoni \\
\hline 1. & $\begin{array}{l}\text { Wadi Abdullah } \\
\text { (Keuchik Ranub Dong) }\end{array}$ & $\begin{array}{l}\text { Kami dari aparatur Gampong Ranub Dong mengucapkan } \\
\text { terima kasih kepada Tim Pengabdian Kepada Masyarakat } \\
\text { UTU yang telah menyelenggarakan kegiatan sangat } \\
\text { bermanfaat ini. Semoga untuk masa yang akan datang } \\
\text { kegiatan ini terus dilakukan mengingat aparatur gampong } \\
\text { sering berganti. }\end{array}$ \\
\hline 2. & $\begin{array}{l}\text { Jaliman } \\
\text { (Keuchik Ranto Panyang Barat) }\end{array}$ & $\begin{array}{l}\text { Pelaksanaan kegiatan ini dapat menambah keterampilan } \\
\text { dan ilmu pengetahuan kepada kami selaku aparatur } \\
\text { gampong. Untuk itu kami mengucapkan terima kasih } \\
\text { kepada Tim Pengabdian Kepada Masyarakat UTU. }\end{array}$ \\
\hline 3. & $\begin{array}{l}\text { Muhammad Nur } \\
\text { (Keuchik Langung) }\end{array}$ & $\begin{array}{l}\text { Dengan adanya pelatihan ini, kami sebagai aparatur } \\
\text { gampong sangat bangga, karena telah menambah } \\
\text { wawasan kami bagaimana mengelola keuangan desa } \\
\text { secara baik dan benar. }\end{array}$ \\
\hline 4. & $\begin{array}{l}\text { Ibnu Hajar } \\
\text { (Keuchik Masjid Tuha) }\end{array}$ & $\begin{array}{l}\text { Pelaksanaan kegiatan ini sangat positif dan menambah } \\
\text { wawasan kami tentang pengelolaan keuangan desa. } \\
\text { Ditambah lagi dengan narasumber yang sangat kompeten } \\
\text { di bidangnya. }\end{array}$ \\
\hline 5. & $\begin{array}{l}\text { Nazaruddin } \\
\text { (Keuchik }\end{array}$ & $\begin{array}{l}\text { Kami sangat mendukung program semacam ini. Kami } \\
\text { mengharapkan untuk masa yang akan datang dapat } \\
\text { dilakukan pelatihan serupa untuk terjun langsung ke } \\
\text { setiap gampong, sehingga lebih banyak masyarakat } \\
\text { gampong paham tentang dana desa. }\end{array}$ \\
\hline
\end{tabular}




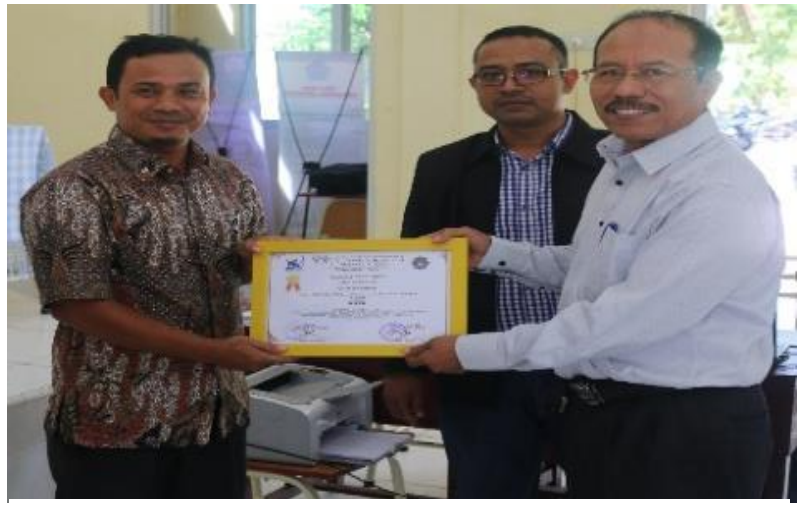

Gambar 1. Rektor UTU Prof. Dr. Jasman J. Ma'ruf, SE, MBA, di dampingi oleh Ketua Tim Pengabdian Kepada Masyarakat, Zainal Putra, SE, MM menyerahkan cinderamata kepada mitra dari BPKD Kabupaten Aceh Barat

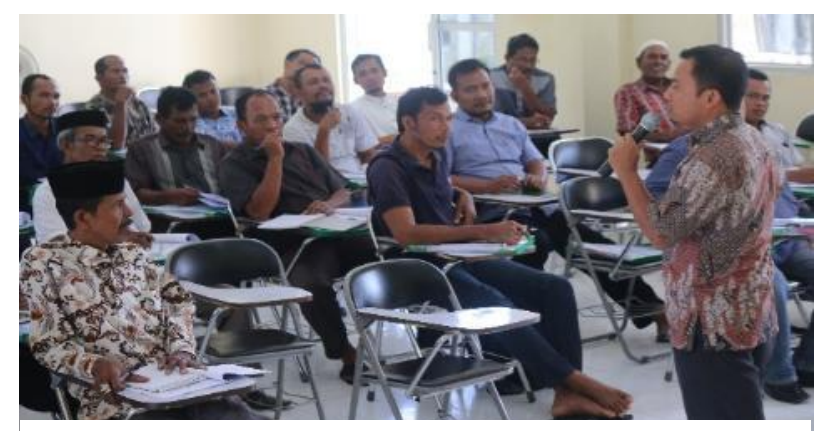

Gambar 4. Ketua Tim Pengabdian Kepada Masyarakat, Zainal Putra, SE, MM sedang memberikan materi pelatihan

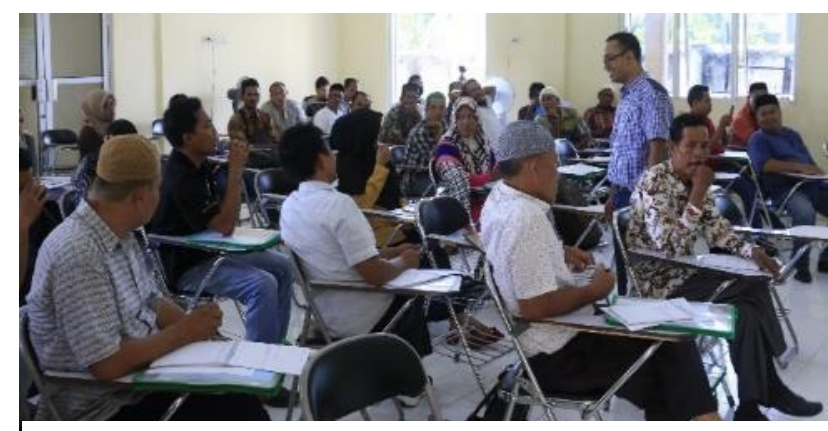

Gambar 5. Salah seorang peserta pelatihan sedang mengajukan pertanyaan kepada narasumber

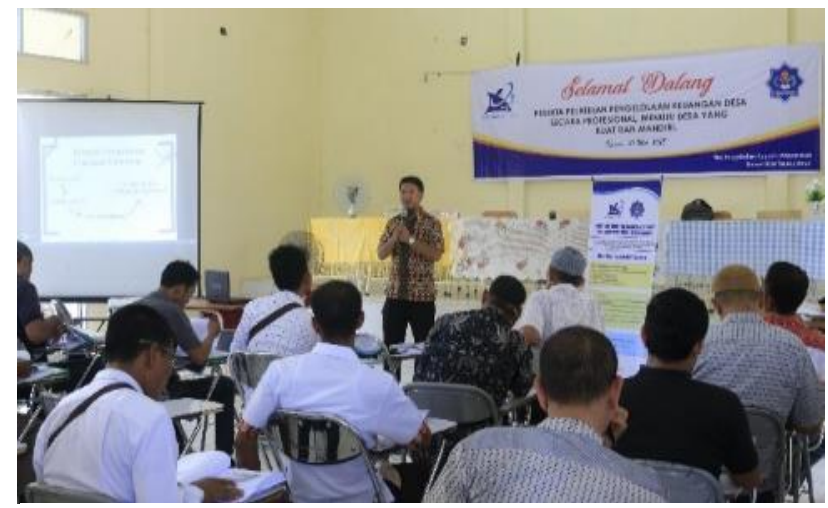

Gambar 2. Tenaga Ahli Keuangan Desa dari DPMG Kabupaten Aceh Barat, Kemal Pasha, SIP, MPA sedang memberikan materi pelatihan

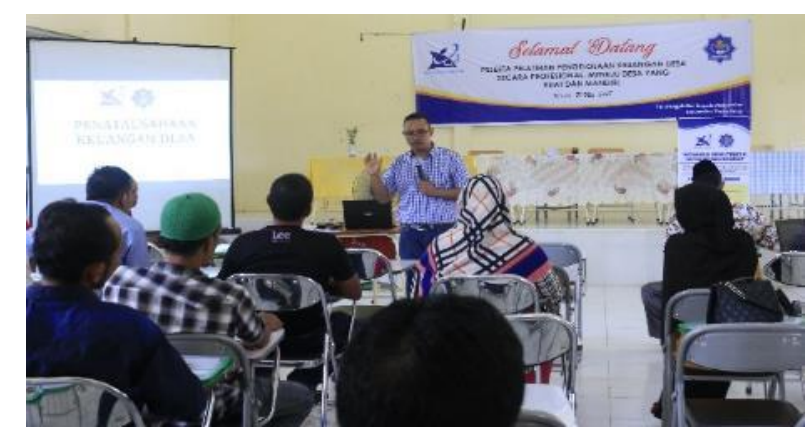

Gambar 3. Tenaga Ahli Keuangan Desa dari BPKD Kabupaten Aceh Barat, Jani Janan, SE, Ak sedang memberikan materi pelatihan

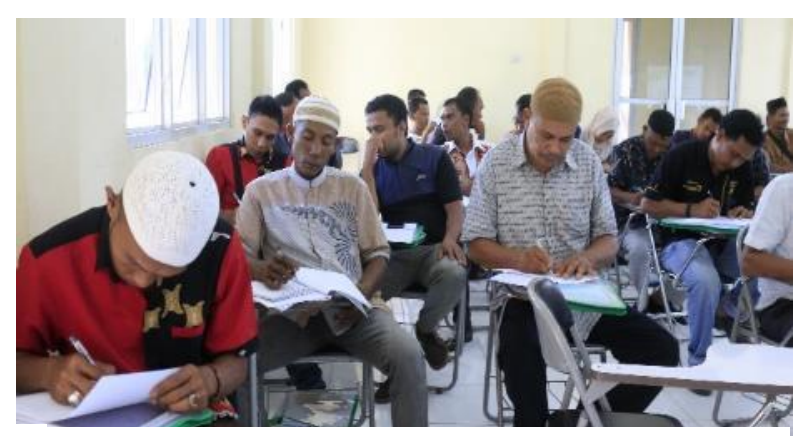

Gambar 6. Peserta pelatihan sedang mengerjakan latihan soal

\section{Simpulan dan Saran}

Pelaksanaan kegiatan ini mendapat dukungan penuh dari pihak mitra, seperti Badan Pengelola Keuangan Daerah Kabupaten Aceh Barat, Dinas Pemberdayaan Masyarakat dan 
Gampong Kabupaten Aceh Barat, Sekretariat Kecamatan Meureubo dan SMA Negeri 1 Meureubo selaku penyedia aula tempat pelaksanaan kegiatan. Selain itu pihak aparatur pemerintah gampong mendapat sambutan yang baik atas inisiatif pelaksanaan kegiatan ini, karena selama ini mereka memang menunggu kegiatan serupa, namun belum ada pihak yang menyelenggarakannya.

Terkait dengan hal tersebut kami menyarankan kepada DRPM Kemenristekdikti supaya untuk masa yang akan datang dapat lebih mempercepat proses penandatanganan kontrak dan juga mempercepat proses pencairan dana kepada pihak pelaksana pengabdian kepada masyarakat, sehingga waktu yang tersedia efektif dalam melaksanakan program.

\section{Ucapan Terima Kasih}

Kami tim pengabdian kepada masyarakat Universitas Teuku Umar mengucapkan terima kasih kepada:

1. DRPM Kemenristekdikti yang telah membiayai program pengabdian ini.

2. LPPM Universitas Teuku Umar yang telah banyak memfasilitasi tim pengabdian kami.

3. Tenaga Kependidikan Fakultas Ekonomi Universitas Teuku Umar, beserta mahasiswa selaku asisten tim pengabdian yang telah begitu banyak membantu kami.

4. BPKD Kabupaten Aceh Barat, DPMG Kabupaten Aceh Barat, Camat Meureubo Kabupaten Aceh Barat dan Kepala SMA Negeri 1 Meureubo yang menjadi mitra yang baik bagi kami.

5. Seluruh aparatur pemerintah gampong dalam Kecamatan Meureubo Kabupaten Aceh Barat yang telah merespon secara baik kegiatan pengabdian yang kami lakukan.

\section{Daftar Pustaka}

Bakri. 2016. Keuchik Dituding Gelapkan Uang Desa. http://aceh.tribunnews.com.

Bakri. 2016. Rapat Dana Desa, Keuchik Pingsan. http://aceh.tribunnews.com.

Iskanda, D. 2105. Oknum Kades di Nagan Diduga Kabur dengan Dana Gampong. http://aceh.tribunnews.com.

Peraturan Menteri Dalam Negeri Nomor Nomor 113 Tahun 2014 Pengelolaan Keuangan Desa.

Peraturan Menteri Desa Nomor 21 Tahun 2015 Prioritas Penggunaan Dana Desa Tahun 2016.

Peraturan Menteri Keuangan Nomor 93 Tahun 2015 Tata Cara Pengalokasian, Penyaluran, Penggunaan, Pemantauan dan Evaluasi Dana Desa. 
Peraturan Presiden Nomor 36 Tahun 2015 APBN Tahun 2015.

Peraturan Presiden Nomor 66 Tahun 2016 APBN Tahun 2016. 